\title{
Investment and Subsidies in Indian Agriculture
}

\author{
Raghbendra Jha
}

Australia South Asia Research Centre

Research School of Pacific \& Asian Studies

Australian National University

Canberra, ACT, Australia

\begin{abstract}
One of the principal elements of the economic reforms program initiated in 1991 was to reduce the fiscal deficit of the central government which, at that time, faced a solvency crisis. This reduction was at least partially achieved by reducing transfers to state governments. As a result, state government budgets faced crises and agriculture, being largely a state subject, was denied adequate investment. This paper reviews the performance of Indian agriculture, particularly in the post-reform period. It attributes this lacklustre performance to the stagnation of agricultural investment whereas there has been a contemporaneous rise in agricultural subsidies. Thus while current operations are being subsidised to some extent resource for augmentation of productive capacity in agriculture are dwindling.
\end{abstract}




\section{Introduction}

It is widely recognised that Indian agriculture is facing difficulties; some would even argue that it is facing a crisis manifested in several dimensions. Agricultural output growth rate has stagnated. As a consequence agricultural employment growth has been low and aggregate unemployment has risen. Slow growth in agriculture has reduced the rate of poverty decline, once corrections are made for the noncomparability of data for the $55^{\text {th }}$ Round of the National Sample Survey (NSS). It is well accepted now that the rate of poverty decline was greater during the 1980s than during the post-reform period. The principal reason for that was even with a lower aggregate growth rate the higher agricultural growth rate during the 1980s increased the demand for labour sufficiently to make a significant dent on poverty. During the post 1991 reform period, although trend real GDP growth rate has been higher, such growth has been concentrated in services and, of late, in high value added manufacturing. This has led to a sharp increase in the demand for skilled labour whereas the stagnation of the agricultural sector has led to inadequate growth in demand for unskilled labour, hence the slow decline in poverty.

The primary purpose of this paper is to provide one possible explanation — the reduction in agricultural investment - for the stagnation of agriculture and argue the case for its redressal. The paper is organised as follows. In section II I briefly overview some aspects of recent agricultural growth in India. In section III I document the recent decline in agricultural investment and the corresponding burgeoning of agricultural subsidies. Indian agriculture has substituted unproductive or less productive current subsidies for capacity enhancing productive capital 
investment and this fact provides an explanation for agriculture’s stagnation. Section

IV concludes.

\section{Some Elements of the Recent Performance of Indian Agriculture}

Table 1 provides synoptic information on the performance of area, production and yield of farming activities in Indian agriculture.

Table 1: Average Growth Rates of Area, Production \& Yield under Foodgrains, Non-fodgrains \& All Crops.

\begin{tabular}{|l|c|c|c|c|c|c|c|c|c|}
\cline { 2 - 10 } \multicolumn{1}{c|}{} & \multicolumn{3}{c|}{ Foodgrains } & \multicolumn{3}{c|}{ Non-foodgrains } & \multicolumn{3}{c|}{ All crops } \\
\cline { 2 - 10 } & Area & Production & Yield & Area & Production & Yield & Area & Production & Yield \\
\hline $\begin{array}{l}1950-51 \text { to } \\
1993-94\end{array}$ & 0.53 & 2.99 & 2.03 & 1.51 & 3.33 & 1.30 & 0.81 & 3.05 & 1.72 \\
\hline $\begin{array}{l}1993-94 \text { to } \\
2004-05\end{array}$ & 0.30 & 1.44 & 0.90 & 0.34 & 2.63 & 1.49 & 0.33 & 1.72 & 1.11 \\
\hline $\begin{array}{l}1950-51 \text { to } \\
1959-60\end{array}$ & 1.64 & 2.79 & 0.99 & 2.06 & 3.13 & -0.25 & 1.91 & 2.81 & 0.56 \\
\hline $\begin{array}{l}1960-61 \text { to } \\
1969-70\end{array}$ & 0.63 & 2.96 & 2.01 & 0.97 & 3.08 & 1.35 & 0.71 & 2.96 & 1.71 \\
\hline $\begin{array}{l}1970-71 \text { to } \\
1979-80\end{array}$ & 0.19 & 1.38 & 0.53 & 0.75 & 1.78 & 0.98 & 0.32 & 1.44 & 0.65 \\
\hline $\begin{array}{l}1980-81 \text { to } \\
1989-90\end{array}$ & -0.02 & 3.33 & 2.88 & 1.10 & 3.89 & 2.24 & 0.24 & 3.45 & 2.57 \\
\hline $\begin{array}{l}1990-91 \text { to } \\
1993-94\end{array}$ & -0.80 & 2.03 & 2.00 & 2.40 & 3.18 & 1.20 & 0.08 & 2.45 & 1.65 \\
\hline $\begin{array}{l}1950-51 \text { to } \\
1989-90\end{array}$ & 0.61 & 2.61 & 1.60 & 1.22 & 2.97 & 1.08 & 0.79 & 2.66 & 1.37 \\
\hline $\begin{array}{l}1990-91 \text { to } \\
2004-05\end{array}$ & -0.07 & 1.64 & 1.27 & 1.03 & 2.81 & 1.39 & 0.25 & 1.96 & 1.29 \\
\hline
\end{tabular}

Source: Author's computation based on Reserve bank of India' Handbook of Statistics on the Indian Economy.

The contrast between the pre-reform and the post-reform periods in respect of the performance of agriculture is quite stark. Even of we define the pre-reform period to go far back as the 1950s, when agricultural operations were subject to very high risks, except for the yield of non-foodgrains the performance in respect of rates of growth of area, production and yield was worse in the post reform period 1990-91 to 2004-05. Except for the growth of area under foodgrains performance during the 1980s was the best. The Green Revolution era was significant for Indian agriculture in more ways 
than one. Whereas the information in Table 1 is at the aggregate level Tables 2 and 3 provide details on yields of major foodgrains and non-foodgrains.

The stark conclusion about the near stagnation of productivity in Indian agriculture in the post reform period at the aggregate can be contrasted with the figures on yields reported for individual crops in Tables 2 and 3. Table 2 shows that yields for major foodgrains grew faster in the 1980s than in the post reform period. The performance of some individual non-foodgrains has, however, been better in the post reform period. However, as shown in Table 1 the performance of all non-foodgrains as a whole remains lacklustre.

Table 2: Growth of Yield of Foodgrains (Kg/hectare) per cent per year

\begin{tabular}{|l|c|c|c|c|c|c|}
\cline { 2 - 7 } \multicolumn{1}{l|}{} & Rice & wheat & $\begin{array}{c}\text { coarse. } \\
\text { cereals }\end{array}$ & total & pulses & $\begin{array}{c}\text { Total } \\
\text { food grain }\end{array}$ \\
\hline $1950 \mathrm{~s}$ & 4.29 & 2.07 & 3.01 & 3.27 & 1.44 & 2.88 \\
\hline $1960 \mathrm{~s}$ & 1.91 & 5.25 & 1.29 & 2.33 & 2.60 & 2.41 \\
\hline $1970 \mathrm{~s}$ & 0.72 & 2.02 & 1.68 & 1.62 & -2.56 & 1.17 \\
\hline $1980 \mathrm{~s}$ & 5.45 & 4.17 & 4.01 & 4.73 & 4.02 & 4.61 \\
\hline $1990 \mathrm{~s}$ & 1.36 & 2.86 & 2.03 & 2.38 & 1.81 & 2.43 \\
\hline 2000 s till 2004-05 & 1.12 & -0.38 & 3.44 & $1.25^{\star}$ & -0.51 & 0.34 \\
\hline $\begin{array}{l}\text { Average for 1950-51 } \\
\text { to 2004-05 }\end{array}$ & 2.57 & 2.96 & 2.49 & $2.73^{*}$ & 1.28 & 2.48 \\
\hline
\end{tabular}

N.B. * Till 2003-04

Source: Reserve Bank of India

Table 3: Growth of Yield of Non-Foodgrains (Kg/hectare) per cent per year

\begin{tabular}{|c|c|c|c|c|c|c|c|c|c|c|}
\hline & \multicolumn{4}{|c|}{ Oilseeds } & \multirow[b]{2}{*}{ Sugarcane } & \multirow[b]{2}{*}{ Tea } & \multirow[b]{2}{*}{ Coffee } & \multirow{2}{*}{$\begin{array}{c}\text { Cotton } \\
\text { (Lint) }\end{array}$} & \multirow{2}{*}{$\begin{array}{l}\text { Jute \& } \\
\text { Mesta }\end{array}$} & \multirow[b]{2}{*}{ Tobacco } \\
\hline & $\begin{array}{l}\text { Ground- } \\
\text { nut }\end{array}$ & $\begin{array}{l}\text { Rapeseed } \\
\text { \& Mustard }\end{array}$ & Soyabean & Total \# & & & & & & \\
\hline $1950 \mathrm{~s}$ & 0.46 & 3.45 & & 1.00 & & & & 4.79 & 0.31 & 0.97 \\
\hline 1960s & 2.11 & 1.57 & & 1.22 & & & & 2.93 & 1.56 & 1.86 \\
\hline 1970s & 1.16 & 5.99 & 11.08 & 1.01 & 2.49 & 2.30 & 5.21 & 0.62 & 0.42 & 2.07 \\
\hline 1980s & 4.18 & 5.42 & 5.30 & 4.80 & 1.27 & 1.61 & 12.11 & 5.29 & 4.37 & 2.56 \\
\hline 1990s & 2.74 & 1.82 & -0.77 & 0.88 & 0.56 & -0.16 & 3.03 & -1.02 & 1.40 & 0.02 \\
\hline $2000 \mathrm{~s}$ & 12.61 & 8.29 & 9.36 & 8.36 & -1.61 & 0.53 & -6.38 & 16.80 & 3.13 & 4.28 \\
\hline $\begin{array}{l}1950-51 \text { to } \\
2004-05\end{array}$ & 2.92 & 3.91 & 5.36 & 2.27 & 1.45 & 1.19 & 4.59 & 4.65 & 1.74 & 1.75 \\
\hline
\end{tabular}

Source: Reserve Bank of India 
Crop yields in India are low by international standards as Table 4 indicates.

Table 4: Comparative Crop Yields 2000-03 (tons per hectare)

\begin{tabular}{|l|c|c|c|}
\hline & India & Developing Countries & World \\
\hline Rice, paddy & 2.9 & 3.8 & 3.9 \\
\hline Wheat & 2.7 & 2.7 & 2.7 \\
\hline Sorghum & 0.8 & 1.1 & 1.3 \\
\hline Pulses & 0.6 & 0.7 & 0.8 \\
\hline Ground nuts & 0.9 & 1.4 & 1.4 \\
\hline Soybeans & 0.9 & 2.1 & 2.3 \\
\hline Cotton lint & 0.2 & 0.5 & 0.6 \\
\hline Sugar Cane & 67 & 64 & 65 \\
\hline
\end{tabular}

Source: FAO (2004)

As table 4 indicates average crop yields in India are low by world standards, ${ }^{1}$ except

for wheat. The performance in respect of wheat is not surprising since well over 80 per cent of the Indian wheat crop has been irrigated. The proportions in respect of the other crops are much lower. That said, by world standards a relatively high proportion of India's crops are grown with irrigation, for which there is substantial subsidy. FAO (2004) estimates that in the three years to 2002 about 21 per cent of the world's irrigated areas were found in India, although India has only 12 per cent of the world's arable land. In the twenty year period 1980-81 to 2001-02 the area under irrigation grew from 50 million hectares (29 per cent of the area of cultivated crops) to 75 million hectares (41 per cent of the area of cultivated crops). Rice and wheat are the major irrigated crops, currently accounting for 32 per cent and 31 per cent of the total irrigated area respectively. Overall 54 per cent of the area sown to rice is now irrigated while 88 per cent of wheat crops are irrigated. In contrast only 13 per cent

\footnotetext{
${ }^{1}$ The Economic Survey for $1998-99$ suggests that India ranks $34^{\text {th }}$ in yields for Sugarcane, $57^{\text {th }}$ for Cotton, $118^{\text {th }}$ for Pulses, and, $51^{\text {st }}$ for Rice in spite of leading in production of these crops. There is also evidence of inefficient use of resources in agriculture and the resulting increased costs of agricultural production. For example 25 times more water/tonne of output is being used to irrigate cotton in India than in Egypt.
} 
and 23 per cent of the areas sown respectively to pulses and oilseeds are irrigated.

Over 90 per cent of the sugar cane area, 42 per cent of the area under fruit and vegetables and a third of the cotton area are irrigated.

One of the most significant consequences of this poor growth performance in the post reform period has been the rise in unemployment in India as shown in Table 5.

Table 5: Unemployment in India, Current Daily Status Basis (percentages)

\begin{tabular}{|c|c|c|c|c|c|c|}
\hline & \multicolumn{2}{|c|}{ 1993-94 } & \multicolumn{2}{|c|}{$1999-00$} & \multicolumn{2}{|c|}{2004} \\
\hline & Rural & Urban & Rural & Urban & Rural & Urban \\
\hline Male & 5.6 & 6.7 & \multirow{2}{*}{7.21} & \multirow{2}{*}{7.65} & 9.0 & 8.1 \\
\hline Female & 5.6 & 10.5 & & & 9.3 & 11.7 \\
\hline
\end{tabular}

Source: Economic Survey, Government of India, 2006-07

Unemployment for both men and women has grown steadily since 1993-94. The paucity of jobs in the rural sector implies that the unemployed flock to the cities raising the urban growth rate as well. The National Rural Employment Guarantee Act will provide at best only 100 days of employment per household for the 200 poorest rural districts at the minimum wage which is, at best, a band-aid solution for those most in need and cannot be construed as a secular increase in the demand for labour which, alone, can make a serious dent on the scourge of rising unemployment in India..

\section{Agricultural Investment and Agricultural Subsidies: Contrasting Experiences}

An important maintained hypothesis of this paper is that stagnant investment has been one of the principal reasons for the stagnation in agriculture. The performance of 
investment in Indian agriculture in comparison to investment in general is sketched in Figure 1 below.

Figure 1

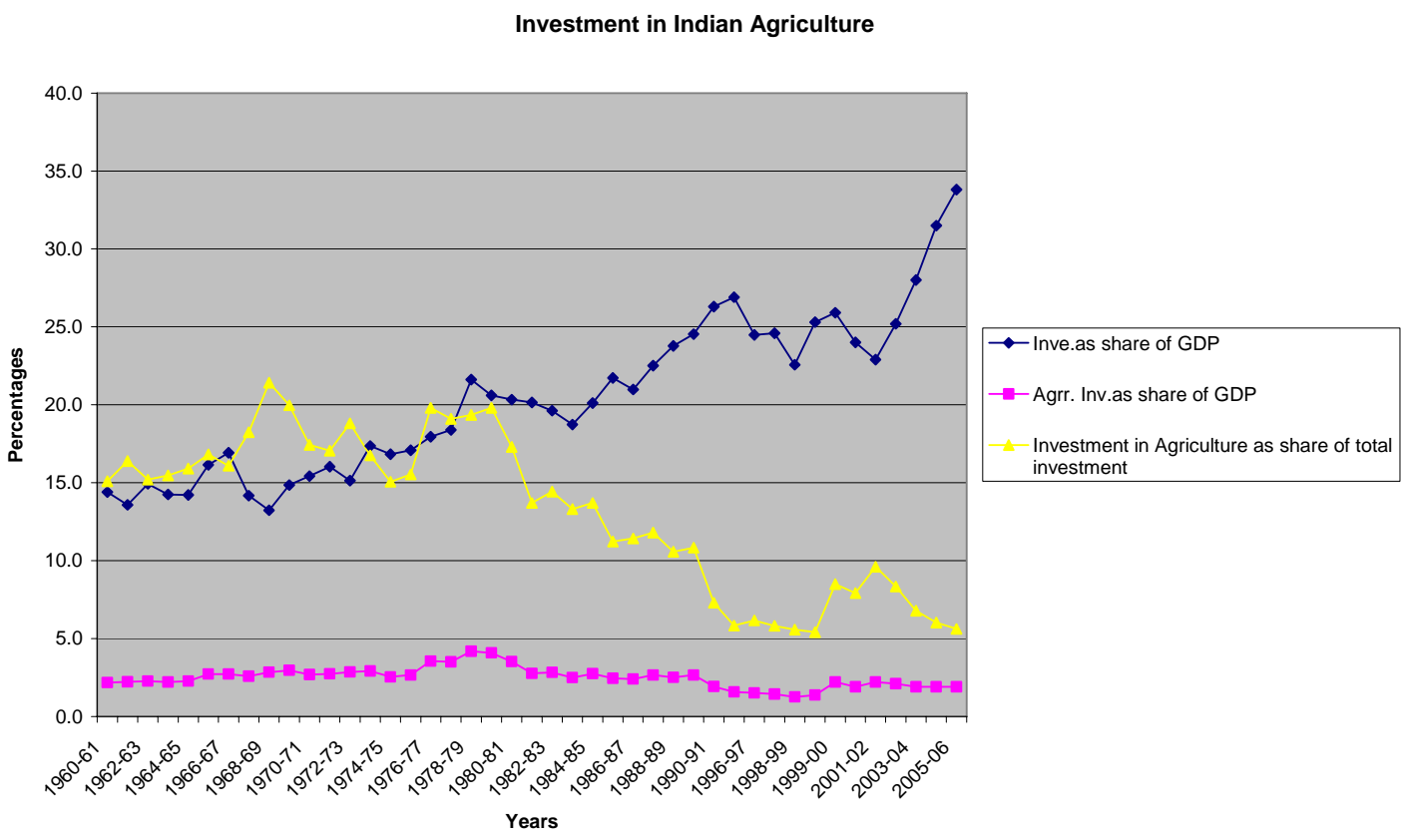

Source: Computed from Figures provided by Reserve Bank of India

As Figure 1 shows whereas investment as a proportion of GDP has been on a rising trend since the 1970s agricultural investment as a share of total investment has been falling since the 1980s. There was a mild revival between 1999-00 and 2002-03 but, since then, agricultural investment as a proportion of GDP has resumed its downward trend. This is in sharp contrast to the spurt in aggregate investment since 1999-00. Agricultural investment as a proportion of GDP has also been falling (Purohit and Reddy 1999).

However, whereas investment in agriculture has been stagnant the subsidy for agriculture has risen sharply (Figure 2). 


\section{Figure 2}

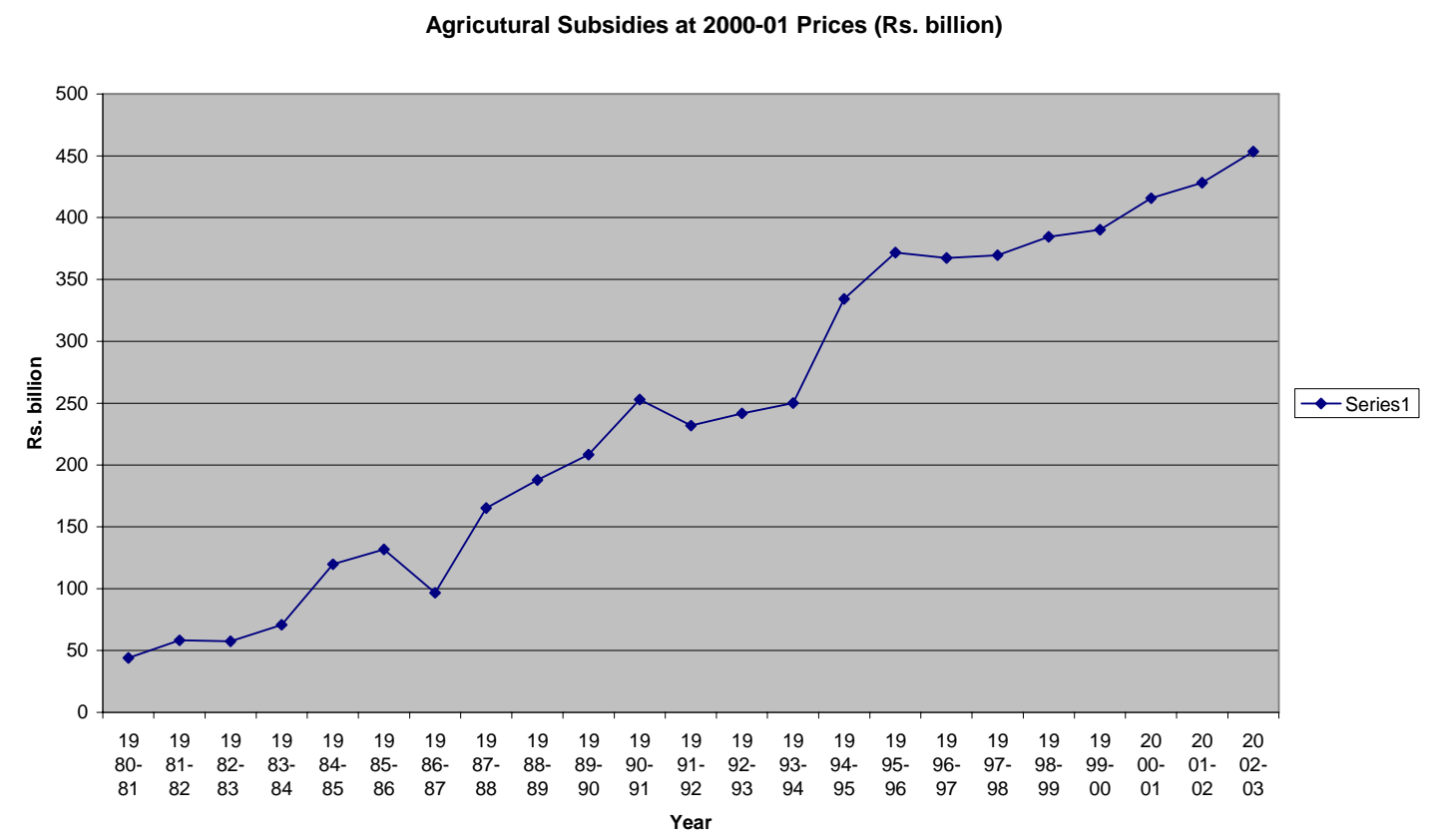

Source: Computed from Mullen et al. (2005)

Gulati and Narayanan (2003) report that there was a sharp rise in the level of subsidies in Indian agriculture for the period 1980-81 to 1999-00. By 1999-00 input subsides on fertiliser, irrigation and power alone accounted for 2.1 per cent of GDP and 8.8 per cent of agricultural output. Power subsidy made up 64 per cent of the total subsidy followed by fertiliser (22 per cent) and irrigation (14 per cent). Of course, these subsidies have had problems associated with them including losses for state electricity boards and delays in the reforms of the power sector (power subsidies), soil damage and other environmental problems (fertiliser subsidies) and salination, lowering of water table and reduction of water supply to urban areas (irrigation). It is far more important to improve technologies for rainfed agriculture. Contributing to the lower agricultural growth was the slowdown in productivity growth. Investment in agriculture was tapering off, most of it was confined to irrigated areas as it was felt that the scope for high productivity investment in rainfed agriculture was limited. 
About two-thirds of cultivation takes place in rainfed areas and with maximal effort this ratio would go down to at most one-half. However, there is some evidence (Fan and Hazell 2000) pointing to the possibility of the productivity of investment being higher in rainfed areas. Thus, one important task for further research would be to identify the types of investment that hold greatest promise in the rainfed areas. We should be wary of the possibility, though, that the marginal productivity of investment in rainfed areas may be high at low levels of capital but taper off quite quickly. The combination of rising subsidies in real terms and stagnant investment implies that whereas there are resources for operational purposes (irrigation, seeds, fertilizers etc.) resources for augmenting the productive capacity of agriculture are dwindling.

Political economy considerations have been a significant factor in the rapid rise of the real value of agricultural subsidies. While some subsidies may be justified there is a widespread view that most of these subsidies are usurped by the more affluent section of farmers. Current subsidies have thus had an inequitable impact. At the same time they contribute to large deficits both at the central and state levels as also to the funds available for servicing the accumulated public debt.

\section{Conclusions}

The current stance of policy towards Indian agriculture is neither efficient nor equitable. The stagnation of agricultural investment has meant that enough productive capacity to sustain agricultural growth has not been forthcoming. At the same time political economy considerations have led to a burgeoning of the agricultural subsidies bill. The subsidy mix has not been well thought out and, more importantly, the subsidies are available for current production and not addition for productive 
capacity. Furthermore, there is widespread evidence that the more affluent farmers are able to garner a disproportionately large part of the subsidies. Hence the subsidy incidence is inequitable. At the same time, the stagnation of agriculture has led to a spillover of problems into other areas particularly, but not exclusively, in the area of unemployment. Indian agricultural subsidies, though at historic high levels, are low when compared to European or US levels. However, there is an urgent need to put into effect an expenditure switch from subsidies to investment to lift Indian agriculture from its current stagnation.

\section{References}

FAO (2004), FAO STAT, database, Rome.

Fan, S. and P. Hazell (2000), "Should Developing Countries Invest More in LessFavoured Areas? — An Empirical Analysis of Rural India”, Economic and Political Weekly, April, pp. 1455-1464.

Gulati, A. and S. Narayanan (2003), Subsidy Syndrome in Indian Agriculture, New Delhi: Oxford University Press.

Mullen, K., Orden, D. and A. Gulati (2005), “Agricultural Policies in India: Producer Support Estimates 1985-2002”, MTID Discussion Paper No. 82, IFPRI, Washington D.C.

Purohit, B. and R. Reddy (1999), “Capital Formation in Indian Agriculture: Issues and Concerns”, NABARD, Occasional Paper 8. 